\title{
An Investigation into the Potential Use of Chelating Agents and Antibiotics as Synchrony Inducers in the Fission Yeast Schizosaccharomyces pombe
}

\author{
By GRAEME M. WALKER* AND JOHN H. DUFFUS \\ Department of Brewing and Biological Sciences, Heriot-Watt University, \\ Edinburgh EH1 $1 H X$, Scotland
}

(Received 20 February 1979)

\begin{abstract}
Following the discoveries that the divalent cation ionophore A23187 and the divalent cation chelating agent EDTA can be used to synchronize yeast cell division, a study has been undertaken of the possible use of other chelating agents and antibiotics which interact with divalent cations in controlling cell division in the fission yeast Schizosaccharomyces pombe. All the agents studied (five chelators and two antibiotics) arrested cell division in growing cultures of this yeast, but only sodium pyrophosphate and citrate induced synchrony of cell division. Novobiocin produced a transient inhibition of cell division, treated cells exhibiting 'endogenous recovery' in the continued presence of the antibiotic. The results obtained are discussed in relation to the hypothesis that the concentration of intracellular $\mathrm{Mg}^{2+}$ regulates cell division.
\end{abstract}

\section{INTRODUCTION}

Cell division in the fission yeast Schizosaccharomyces pombe may be regulated by controlled applications of the antibiotic ionophore A23187 (Duffus \& Paterson, 1974a) and the chelating agent EDTA (Ahluwalia et al., 1978). Both agents inhibit cell division rapidly when added at appropriate concentrations to growing cultures of $S$. pombe; when the cells are released from this inhibition by inoculation into fresh medium, they progress through subsequent divisions in a synchronous fashion. Similar results have been obtained with the budding yeast Kluyveromyces fragilis (Penman \& Duffus, 1975; Walker, 1978). These phenomena have been explained on the basis of altered availability of $\mathrm{Mg}^{2+}$ affecting spindle formation and cell division as suggested by Duffus \& Paterson $(1974 a, b)$. If ionophore A23187 and EDTA are able to control cell division in yeast by limiting $\mathbf{M g}^{2+}$ supply, any other agents which can produce the same chemical effect should act similarly. We decided to investigate this possibility and in this paper discuss the results obtained with five divalent metal cation chelating agents and two $\mathrm{Mg}^{2+}$-sequestering antibiotics in attempts to induce cell division synchrony in $S$. pombe.

\section{METHODS}

Organisms and growth conditions. Schizosaccharomyces pombe NCYC 132 (ATCC 24751) was aerobically propagated in Edinburgh Minimal Medium no. 2 (EMM2) (Mitchison, 1970) at $32{ }^{\circ} \mathrm{C}$ in an orbital incubator operating at $160 \mathrm{rev} . \mathrm{min}^{-1}$. Subculturing of the cells was carried out weekly by inoculating stationaryphase cells into $10 \mathrm{ml}$ EMM2. Small volumes (generally $1 \mathrm{ml}$ ) of actively dividing precultures were used to initiate experimental cultures which were grown in cotton-plugged Erlenmeyer flasks. Cell numbers were

* Present address: Biological Institute of the Carlsberg Foundation, 16 Tagensvej, Copenhagen N., DK 2200, Denmark. 
determined in an improved Neubauer haemocytometer (Weber), using the criterion employed by Mitchison (1970) that cells were not considered to have divided until the constriction or 'notch' appearing between two daughter cells was observed. The cell plate index was calculated as the percentage of cells which showed a cell plate; this is equivalent to the mitotic index of higher eukaryotes. To prevent cell clumping from affecting the accuracy of cell number determinations, culture samples $(1 \mathrm{ml})$ were routinely sonicated at an amplitude of $16 \mu \mathrm{m}$ (peak to peak) for $30 \mathrm{~s}$ using the titanium exponential microprobe of an MSE $150 \mathrm{~W}$ ultrasonic disintegrator.

Chelating agents and antibiotics. The chelating agents used were tetra-sodium pyrophosphate (SP), citric acid (CA), 8-hydroxyquinoline (HQ) (all analytical reagent grade, from BDH), 1,10-phenanthroline (OP) and EGTA (both from Sigma). SP and CA were added directly to growing cultures and the medium pH was adjusted to 5.5. Both $\mathrm{HQ}$ and $\mathrm{OP}$ were first dissolved in a minimal volume (generally $2 \mathrm{ml}$ ) of $0 \cdot 1 \mathrm{M}-\mathrm{HCl}$ and then added to experimental cultures; equal volumes of $0.1 \mathrm{M}-\mathrm{HCl}$ (without chelating agent) were added to controls. EGTA was first dissolved in a minimal volume of $0 \cdot 1 \mathrm{M}-\mathrm{NaOH}$, neutralized with $\mathrm{HCl}$ and then added to experimental cultures; neutralized alkali (without EGTA) was added to controls.

The antibiotics used were novobiocin and lomofungin (5-formyl-1-methoxycarbonyl-4,6,8-trihydroxyphenazine). Novobiocin (from Boehringer) was added directly to growing cultures of $S$. pombe. Lomofungin (a generous gift of Dr G. B. Whitfield, Upjohn Co., Kalamazoo, Michigan, U.S.A.) is not readily soluble in EMM2 and so stock solutions of this antibiotic were first prepared by dissolving it in analytical grade dimethyl sulphoxide (DMSO) and suitably diluting it with distilled water. Parallel control cultures were set up to which diluted DMSO (without lomofungin) was added. The final concentration of DMSO in cultures was always less than $1 \%(\mathrm{v} / \mathrm{y})$.

The minimum concentrations of the above agents required to inhibit cell division rapidly and completely in early exponential-phase cultures (cell density $1 \times 10^{6}$ to $3 \times 10^{6}$ cells $\mathrm{ml}^{-1}$ ) were estimated by comparing the increases in cell numbers in treated cultures with appropriate controls. These concentrations were then used in an attempt to induce synchrony of cell division by the following modification of the method employed by Ahluwalia et al. (1978) for EDTA synchronization of $S$. pombe. Exponentially growing cells (100 ml culture) were exposed to the agents for $1 \mathrm{~h}$, quickly harvested by Millipore membrane (1.2 $\mu \mathrm{m}$ pore size) filtration, washed with glass-distilled water and finally re-inoculated into fresh EMM2 (which lacked chelators or antibiotics). This procedure was carried out at room temperature and generally took less than $5 \mathrm{~min}$ to complete. Identically treated control cultures, referred to as 'filtration controls' (omitting only the chelating agent or antibiotic treatment), were set up in parallel with experimental cultures.

\section{RESULTS}

\section{Studies with chelating agents}

Sodium pyrophosphate (SP), like all pyrophosphates, is a powerful chelating agent for $\mathrm{Mg}^{2+}$. It forms a chelate ring when the negatively charged oxygen atoms attached to each phosphorus co-ordinate to the metal atom. Structurally related compounds of biological interest are also powerful chelators: for example, ATP, ADP and AMP. At $40 \mathrm{~mm}$, SP arrested cell division in $S$. pombe rapidly and completely (Fig. $1 a$ ). The effect of using a $1 \mathrm{~h}$ pulse of $40 \mathrm{~mm}-\mathrm{SP}$ on a growing culture is shown in Fig. 1 (b). Cells began a synchronous recovery $1.5 \mathrm{~h}$ after completion of the pulse. This synchrony was characterized by a peak in the cell plate index of about $17 \%$ just prior to cell division, followed by a complete doubling of cell numbers over a period of about $1 \mathrm{~h}$. The Engelberg Synchronization Index (Engelberg, 1961) of this synchronous division was $56 \%$, as calculated by the method of Bakke \& Pettersen (1976). About 2.5 h (the normal generation time for $S$. pombe in EMM2) after the start of the first synchronous division, the cells began a second synchronous division. The filtration control culture (Fig. $1 b$ ), however, continued to divide exponentially after re-inoculation into fresh medium and maintained a constant cell plate index of about $6 \%$, indicative of asynchrony. Other filtration controls (not shown), which were run in parallel with subsequent inhibitor-pulse experiments, behaved similarly.

Citric acid (CA) is a powerful chelating agent for $\mathrm{Mg}^{2+}$ (O'Sullivan, 1969). It can lose protons from any of its three acidic carboxyl groups and thus co-ordinate with the ions. At $50 \mathrm{~mm}$, CA rapidly and completely inhibited cell division in $S$. pombe (Fig. $2 a$ ). The effect of a $1 \mathrm{~h}$ pulse of $50 \mathrm{~mm}-\mathrm{CA}$ on a growing culture is shown in Fig. 2(b). The pattern of synchrony is similar to that observed with SP (Fig. $1 b$ ) and the CA-treated culture displayed an Engelberg Synchronization Index of $58 \%$ for the first division. 

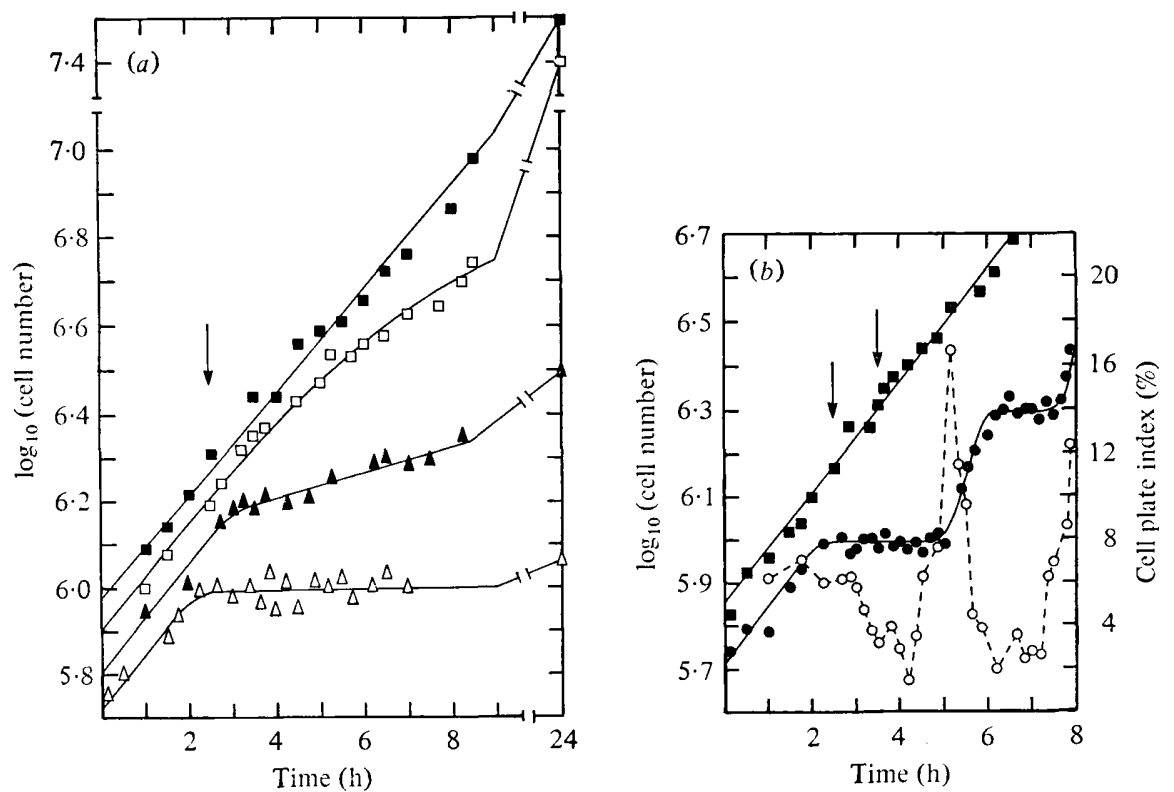

Fig. 1. (a) Inhibition of cell division in $S$. pombe by tetra-sodium pyrophosphate (SP). The chelator was added to cultures growing in EMM 2 at $32^{\circ} \mathrm{C}$ at the time indicated by the arrow, at the following concentrations: $\square, 0$ (control); $\square, 5 \mathrm{mM} ; \Delta, 20 \mathrm{~mm} ; \triangle, 40 \mathrm{~mm}$.

(b) Synchronization of cell division in $S$. pombe with SP $(40 \mathrm{mM}, 1 \mathrm{~h})$. The chelator was added to cultures growing in EMM2 at $32{ }^{\circ} \mathrm{C}$ at the time indicated by the first arrow, and cultures were harvested and inoculated into fresh EMM2 at the time indicated by the second arrow. The control culture (no SP treatment) maintained a constant cell plate index of about $6 \% . \square, \log _{10}$ (cell number) in control culture; $\bigcirc, \log _{10}$ (cell number) in SP-treated culture; $\bigcirc$, cell plate index of SP-treated culture.
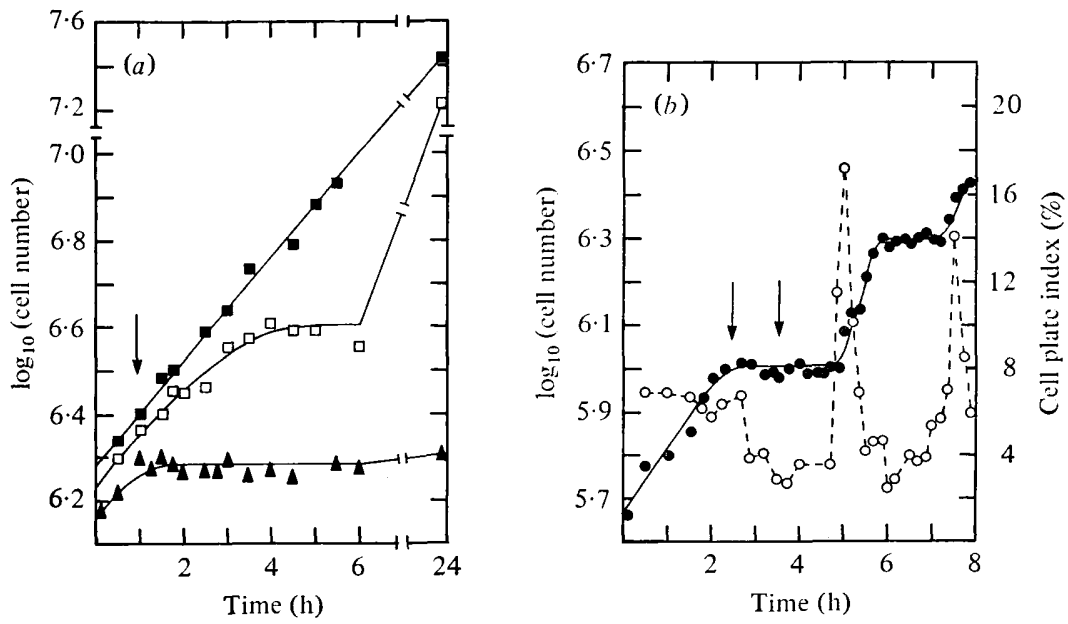

Fig. 2. (a) Inhibition of cell division in $S$. pombe by citric acid (CA). The chelator was added to cultures growing in EMM2 at $32{ }^{\circ} \mathrm{C}$ at the time indicated by the arrow, at the following concentrations: $\square, 0$ (control); $\square, 25 \mathrm{~mm} ; \Delta, 50 \mathrm{~mm}$.

(b) Synchronization of cell division in $S$. pombe with $\mathrm{CA}(50 \mathrm{~mm}, 1 \mathrm{~h})$. A control culture (no CA treatment) behaved similarly to that described in Fig. 1 (b). (Arrows as in Fig. 1 b.) $\bigcirc, \log _{10}$ (cell number); $O$, cell plate index. 

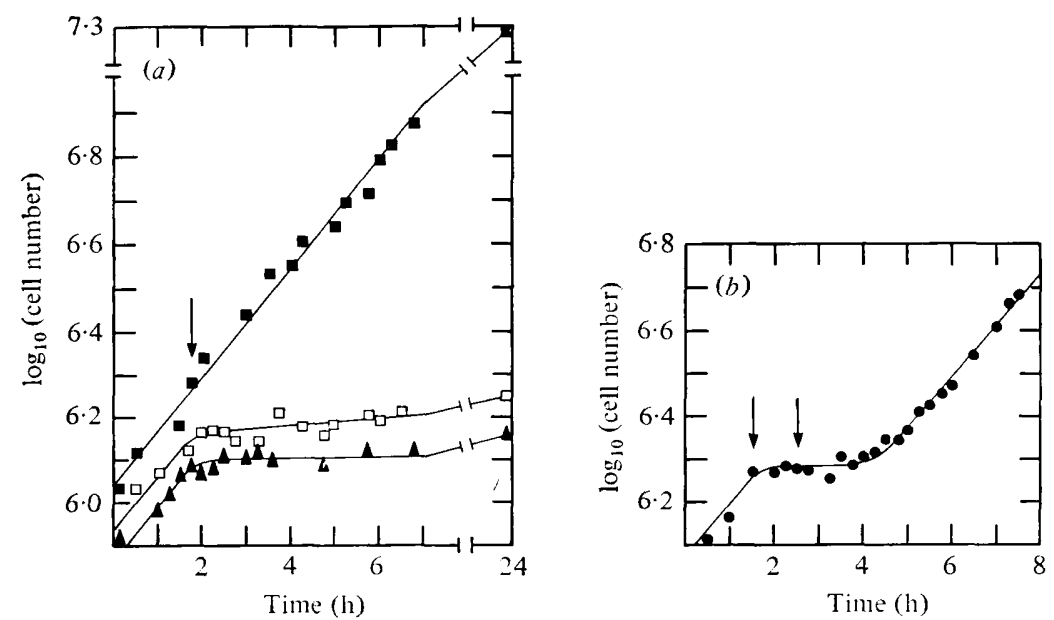

Fig. 3. (a) Inhibition of cell division in $S$. pombe by 8-hydroxyquinoline (HQ). The chelator was added to cultures growing in EMM2 at $32{ }^{\circ} \mathrm{C}$ at the time indicated by the arrow, at the following concentrations: $\square, 0$ (control); $\square, 0.05 \mathrm{~mm} ; \Delta, 0.10 \mathrm{~mm}$.

(b) Effect of a $1 \mathrm{~h}$ pulse of $0.05 \mathrm{mM}-\mathrm{HQ}$ on cell division in $S$. pombe. A control culture (no HQ treatment) behaved similarly to that described in Fig. 1(b). (Arrows as in Fig. 1b.)

8-Hydroxyquinoline (HQ) possesses an acidic hydroxyl group and its ability to chelate is strongly pH dependent (O'Sullivan, 1969). HQ is used extensively in the analysis of metals by gravimetric, volumetric or colorimetric procedures and has been shown by Albert (1958) to exert antibacterial and antifungal properties through its metal chelates. The complete inhibition of cell division in $S$. pombe by HQ was achieved with relatively low concentrations (compared with SP and CA), as shown in Fig. 3(a). Cells continued to grow exponentially and asynchronously after a short lag phase following release from a $1 \mathrm{~h}$ pulse of 0.05 mM-HQ (Fig. $3 b$ ).

1,10 -Phenanthroline (OP) is a chelating agent exhibiting a high selectivity for $\mathrm{Zn}^{2+}$ (O'Sullivan, 1969) and has been widely used in the removal of zinc from zinc metalloenzymes. It has also been employed in the spectrophotometric determination of iron and in some areas of cancer chemotherapy as an antitumour agent (Bell, 1977). At 0.5 mM, OP caused an immediate and lasting inhibition of cell division when applied to an actively dividing culture of $S$. pombe (Fig. $4 a$ ). The effect of a $1 \mathrm{~h}$ pulse of $0.5 \mathrm{~mm}$-OP on a growing culture is shown in Fig. 4(b); the cells continued to divide exponentially after the pulse.

EGTA belongs to the group of aminopolycarboxylic acids, known as 'complexones,' which are highly effective chelating agents and whose structures are essentially derived from the amino acid glycine. EGTA exhibits a high selectivity toward $\mathrm{Ca}^{2+}$ and is commonly used in analytical titrations to determine the free concentration of $\mathrm{Ca}^{2+}$ in solution. At $15 \mathrm{mM}$, EGTA produced an immediate inhibition of cell division in $S$. pombe, but a partial recovery of the cells was observed after an extended growth period (Fig. $5 a$ ). At $5 \mathrm{~mm}$, EGTA only became fully inhibitory after about $2 \cdot 5 \mathrm{~h}$. Figure $5(b)$ shows the effect of a $1 \mathrm{~h}$ pulse of 15 mM-EGTA on a growing culture of $S$. pombe. The cells behaved in a manner essentially similar to that observed after pulsing with either HQ or OP.

\section{Studies with antibiotics}

The biological effects of the antibiotic novobiocin are primarily due to its combination with intracellular $\mathrm{Mg}^{2+}$ (Brock, 1967). It is understood that novobiocin can form chargetransfer complexes with $\mathrm{Mg}^{2+}$ in which transfer of an electron occurs from the ligand to the metal, or in the reverse direction; transfer in the first direction effectively reduces the 

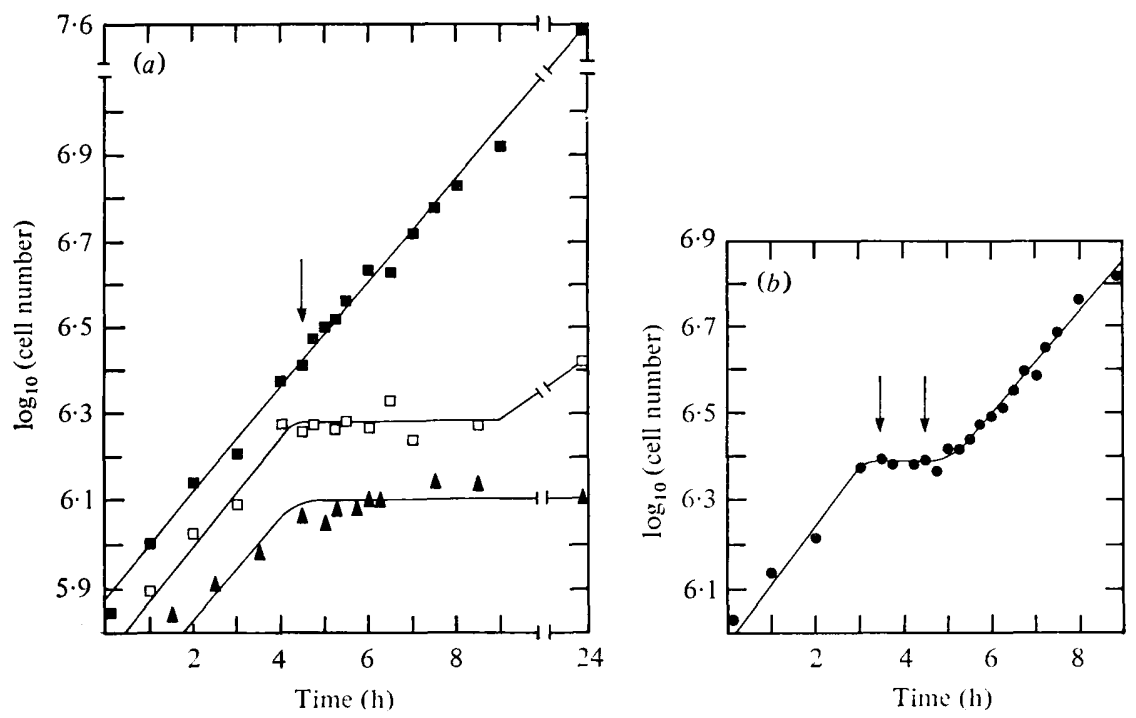

Fig. 4. (a) Inhibition of cell division in $S$. pombe by 1,10-phenanthroline (OP). The chelator was added to cultures growing in EMM2 at $32^{\circ} \mathrm{C}$ at the time indicated by the arrow, at the following concentrations: $\square, 0$ (control); $\square, 0.5 \mathrm{~mm} ; \Delta, 2.5 \mathrm{~mm}$.

(b) Effect of a $1 \mathrm{~h}$ pulse of $0.5 \mathrm{~mm}-\mathrm{OP}$ on cell division in $S$. pombe. A control culture (no OP treatment) behaved similarly to that described in Fig. 1(b). (Arrows as in Fig. 1b.)
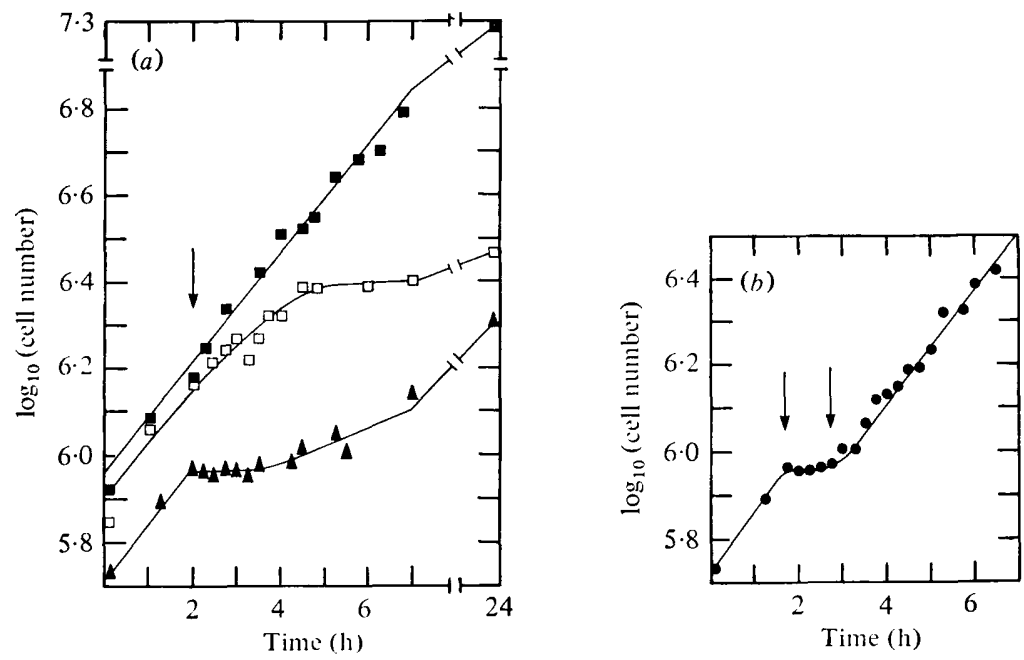

Fig. 5. (a) Inhibition of cell division in $S$. pombe by EGTA. The chelator was added to cultures growing in EMM2 at $32{ }^{\circ} \mathrm{C}$ at the time indicated by the arrow, at the following concentrations: $\square, 0$ (control); $\square, 5 \mathrm{~mm} ; \Delta, 15 \mathrm{~mm}$.

(b) Effect of a $1 \mathrm{~h}$ pulse of $15 \mathrm{~mm}$-EGTA on cell division in $S$. pombe. A control culture (no EGTA treatment) behaved similarly to that described in Fig. 1(b). (Arrows as in Fig. $1 b$ ). 
metal; transfer from metal to ligand is an oxidation process. Novobiocin, by so interacting with $\mathrm{Mg}^{2+}$, is able to produce essentially a state of $\mathbf{M g}^{2+}$ deficiency in cells. Figure 6 shows the effect of adding novobiocin to a growing culture of $S$. pombe. Cell division ceased after about $1 \mathrm{~h}$, and during exposure to the antibiotic cells ceased dividing for a further hour, after which time they began to recover. This 'endogenous recovery' of cell division (Fig. 6) continued exponentially when novobiocin concentrations of 250 and $500 \mu \mathrm{g} \mathrm{ml}^{-1}$ were employed. At higher concentrations, the antibiotic came out of solution.

Lomofungin is an antibiotic extracted from Streptomyces lomondensis which inhibits growth of a variety of pathogenic fungi, yeasts and both Gram-positive and Gram-negative bacteria (Johnson \& Dietz, 1969). In molecular terms, lomofungin is an effective chelator of both $\mathrm{Mg}^{2+}$ and $\mathrm{Mn}^{2+}$ (Fraser \& Creanor, 1975). Figure 7(a) shows that the minimum inhibitory concentration of lomofungin for a growing culture of $S$. pombe was $2.5 \mu \mathrm{g} \mathrm{ml}^{-1}$. At $1 \mu \mathrm{g} \mathrm{ml}^{-1}$, the antibiotic produced only a partial inhibition of cell division from which the cells recovered after a prolonged growth period of $24 \mathrm{~h}$. The effect of exposing a growing culture of $S$. pombe to a $1 \mathrm{~h}$ pulse of lomofungin at $2.5 \mu \mathrm{g} \mathrm{ml}^{-1}$ is shown in Fig. $7(b)$. The cells recovered from the pulse with a greatly decreased growth rate compared with an appropriate control culture. In addition, we noted that lomofungin at concentrations of greater than $5.0 \mu \mathrm{g} \mathrm{ml}^{-1}$ in growing cultures stained the nuclei of $S$. pombe cells intensely in a manner similar to that observed by Kopecká (1976) in Schizosaccharomyces versatilis.

\section{DISCUSSION}

Our results show that, of the chelating agents and antibiotics studied, only SP and CA could be used to induce cell division synchrony in the fission yeast $S$. pombe. This supplements previous findings (Duffus \& Paterson, 1974a; Ahluwalia et al., 1978) that the cell cycle of this organism can be regulated by A23187 and EDTA, agents capable of altering cell $\mathrm{Mg}^{2+}$ levels.

Uptake of $\mathrm{Mg}^{2+}$ is an essential prerequisite for cell division in yeast (Duffus \& Paterson, $1974 a, b$; Ahluwalia et al., 1978; Walker, 1978). SP and CA are highly effective chelating agents for $\mathrm{Mg}^{2+}$ (O'Sullivan, 1969) and so it is likely that the major effect of these agents on growing yeast cells occurs by consequence of removal of free $\mathrm{Mg}^{2+}$, both from the growth medium and the cells. Rubin (1975) used SP in experiments with chick embryo cultures and also concluded that the biological effects of this chelator are primarily due to selective reduction in the availability of cell $\mathrm{Mg}^{2+}$. The possibility that SP and CA act by some mechanism other than their ability to chelate cannot be overlooked, but in the absence of clear evidence of such a process it will be assumed that chelation (especially of $\mathrm{Mg}^{2+}$ ) is the crucial factor which first inhibits and then permits synchronization of cell division in $S$. pombe. The induction synchrony phenomena (Figs $1 b$ and $2 b$ ) brought about by short pulses of SP and CA may then be explained on the basis of adjustment of intracellular $\mathrm{Mg}^{2+}$ concentrations to a low and constant level. This level may be characteristic of a point in the cell division cycle just prior to cell division (Duffus \& Paterson, 1974b), and it is envisaged that cells treated with SP or CA will collect together at this point after which further progress towards division will require $\mathrm{Mg}^{2+}$. When cells are released from short pulses of SP or CA by inoculation into fresh medium, normal cell $\mathrm{Mg}^{2+}$ levels can be restored thus enabling the cells to progress towards their next division in synchrony. This also serves to explain the mechanism whereby A23187 and EDTA can regulate the cell division cycle in $S$. pombe.

The time between the onset of the first and second divisions in SP and CA synchronized cultures (Figs $1 b$ and $2 b$ ) correlates well with the normal cell cycle time of $S$. pombe, suggesting that these agents do not grossly distort the cycle. Further support for this view comes from an examination of the timing of cell plate index peaks which appear to occur at a constant time prior to the mid-point of doubling in cell numbers. 


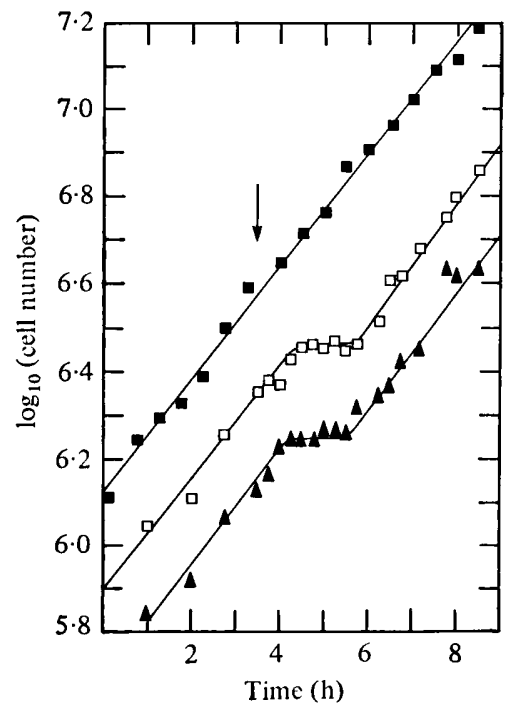

Fig. 6. Inhibition of cell division in S. pombe by novobiocin and subsequent 'endogenous recovery'. The antibiotic was added to cultures growing in EMM 2 at $32{ }^{\circ} \mathrm{C}$ at the time indicated by the arrow, at the following concentrations: $\square, 0$ (control); $\square, 250 \mu \mathrm{g} \mathrm{ml}^{-1} ; \Delta, 500 \mu \mathrm{g} \mathrm{ml}^{-1}$.
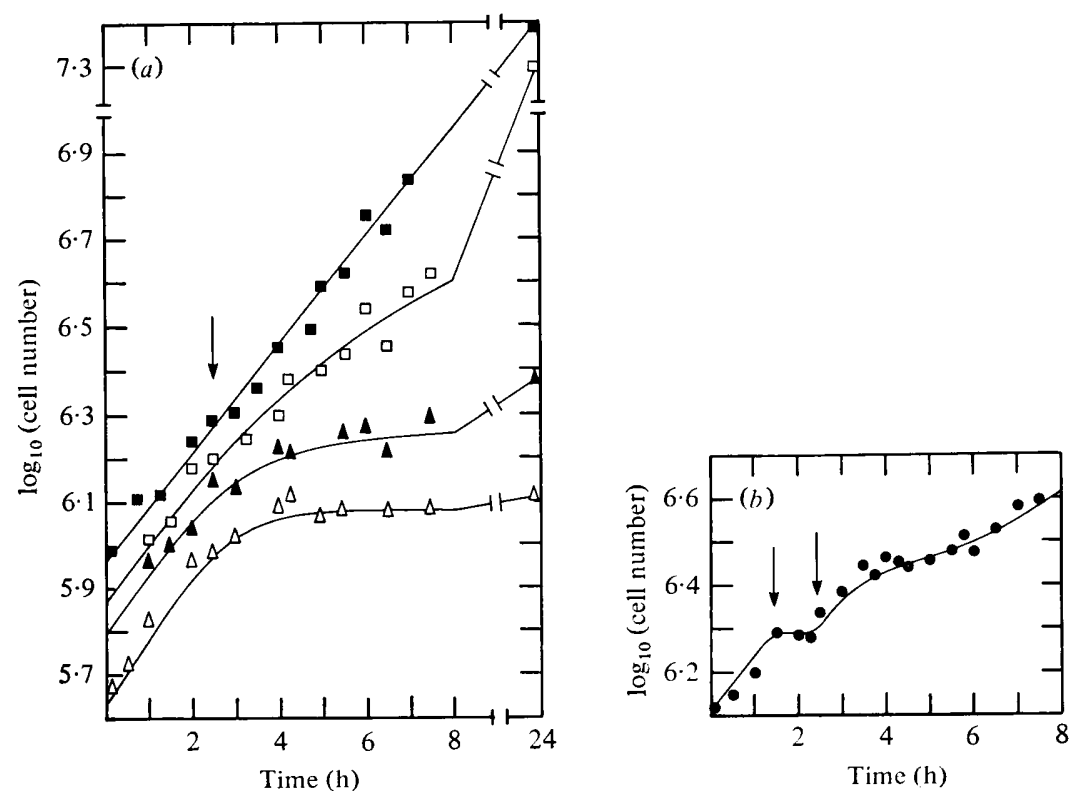

Fig. 7. (a) Inhibition of cell division in $S$. pombe by lomofungin. The antibiotic was added to cultures growing in EMM2 at $32{ }^{\circ} \mathrm{C}$ at the time indicated by the arrow, at the following concentrations: 口, 0 (control); $\square, 1 \mu \mathrm{g} \mathrm{ml}^{-1} ; \Delta, 2 \cdot 5 \mu \mathrm{g} \mathrm{ml}^{-1} ; \triangle, 5 \mu \mathrm{g} \mathrm{ml}^{-1}$.

(b) Effect of a 1 h pulse of lomofungin at $2.5 \mu \mathrm{g} \mathrm{ml}^{-1}$ on cell division in $S$. pombe. A control culture (no lomofungin treatment) behaved similarly to that described in Fig. $1(b)$. (Arrows as in Fig. 1b.)

Chelating agents like SP, CA and EDTA differ from more classical synchrony inducers like DNA synthesis inhibitors (Mitchison \& Creanor, 1971) in one important aspect. This lies in the time the cells in an exponential culture are exposed to the agents. DNA synthesis inhibitors, like 2 '-deoxyadenosine, rely on cells completing their cycles up to a 
transition point, and this necessitates exposure times lasting one complete cell cycle. Chelating agents, on the other hand, act very quickly (only a fraction of the normal cycle time) on cells at different stages in the cycle and the efficient conversion from asynchrony to synchrony seems to occur by resetting an intrinsic biological clock which controls cell division. $\mathrm{Mg}^{2+}$ is a good candidate to provide the timing mechanism in such a clock. The basis of a working hypothesis which assigns to $\mathrm{Mg}^{2+}$ a specific regulatory role in the yeast cell division cycle has been outlined elsewhere (Duffus \& Paterson, 1974a, $b$; Ahluwalia et al., 1978) and is being developed further.

The other chelating agents used in this study, HQ, OP and EGTA, while inhibiting cell division in $S$. pombe, all failed to induce synchrony of cell division when used according to the experimental rationale employed for SP, CA and EDTA. This must be due to a general inhibition of cell division which does not involve cell division cycle arrest at specific points. As EGTA and OP have much greater affinities for $\mathrm{Ca}^{2+}$ and $\mathrm{Zn}^{2+}$, respectively, than for $\mathrm{Mg}^{2+}$, failure of these agents to induce synchrony is not surprising if $\mathrm{Mg}^{2+}$ regulates cell division as postulated. The observation that EGTA inhibits cell division in $S$. pombe is unexpected because $\mathrm{Ca}^{2+}$ does not appear to be essential for growth and division in this yeast (Walker, 1978). It would seem, therefore, that some property of EGTA other than its $\mathrm{Ca}^{2+}$-chelating role is involved. For example, EGTA has been shown to interfere with accumulation of cyclic AMP (Harfield \& Tenenhouse, 1973) which is known to play a multifunctional role in cell division (Berridge, 1976).

The failure of HQ to induce synchrony in $S$. pombe is at first sight surprising in view of the success of SP and CA, since $\mathrm{HQ}$ is also a strong $\mathrm{Mg}^{2+}$ chelator. However, the inhibitory effects of both HQ and OP on cell division may be related to an inhibition of yeast RNA synthesis (Fraser \& Creanor, 1974; Johnston \& Singer, 1978). Inhibition is brought about by chelation of $\mathrm{Mg}^{2+}, \mathrm{Mn}^{2+}$ and $\mathrm{Zn}^{2+}$ which are known to be essential for yeast RNA polymerase activity. Johnston \& Singer (1978) found that both HQ and OP cause a $G_{1}$ arrest in the cell cycle of Saccharomyces cerevisiae. They found that zinc salts fully reversed the inhibitory effects of these agents and that their primary action was the inhibition of ribosomal RNA synthesis in $\mathrm{G}_{1}$. This is in contrast to the present results in $S$. pombe (Figs $3 b$ and $4 b$ ) which seem to rule out a specific cell cycle arrest by these agents. Direct effects of HQ and OP, other than their chelating ability, may also be important, and it is significant in this respect that Tjio \& Levan (1950) found that HQ induced breakdown of the mitotic spindle in plants in a manner comparable to that of the antimicrotubular alkaloid colchicine.

The inhibition of cell division by the antibiotic novobiocin observed in $S$. pombe (Fig. 6 ) has been observed previously in Saccharomyces cerevisiae by Shockman \&!Lampen (1962) and in Escherichia coli by Smith \& Davis (1967). The fact that novobiocin took about an hour to produce this inhibition in $S$. pombe may be related to inhibition of DNA and RNA synthesis, as demonstrated in bacterial cells in the presence of this antibiotic (Smith \& Davis, 1967; Staudenbauer, 1975). As has previously been mentioned, novobiocin forms a charge-transfer complex with $\mathrm{Mg}^{2+}$ (Brock, 1967) and so may inhibit the various nucleic acid polymerases known to possess absolute requirements for this ion. The 'endogenous recovery' from inhibition by novobiocin in $S$. pombe occurs about an hour after the start of cell division inhibition. Reversibility of the antibiotic's inhibitory effect has also been observed in $E$. coli by Smith \& Davis (1967). The recovery of $S$. pombe cell division under the continuing influence of the antibiotic may be explained in a number of ways, for example on the basis of enzymic degradation of novobiocin by the cells, or by increasing $\mathrm{Mg}^{2+}$ transport over a period, which would have the effect of reversing novobiocin inhibition because (at the concentrations used) the pre-saturated antibiotic would be unable to bind to more incoming $\mathrm{Mg}^{2+}$.

The effects of the antibiotic chelating agent lomofungin are similar to those of $\mathrm{HQ}$ (Fraser \& Creanor, 1975), where the inhibition of DNA-dependent RNA polymerase 
activity by these agents almost certainly occurs through the ability to chelate $\mathrm{Mg}^{2+}$ and $\mathrm{Mn}^{2+}$. Complete inhibition of cell division in $S$. pombe by the highest concentration of the antibiotic employed $\left(5 \mu \mathrm{g} \mathrm{ml}^{-1}\right)$ took about $1.5 \mathrm{~h}$ (Fig. $\left.7 a\right)$. This is a much slower response than that observed for effective concentrations of $\mathrm{HQ}$ and may be related to a general inhibition of cell growth dependent on continued RNA synthesis. The failure of lomofungin to induce synchrony of cell division in $S$. pombe, as shown in Fig. $7(b)$, where after $1 \mathrm{~h}$ exposure a greatly reduced rate of cell number increase compared to the control was observed, may be related to the binding affinity of the antibiotic to the cell nucleus. The observation that lomofungin immediately and intensely stained the nucleus of $S$. pombe may indicate that the antibiotic binds irreversibly to nuclear sites. This would explain the failure of inoculation into fresh medium to reverse fully the antibiotic's inhibitory effects.

In conclusion, our results show that specific $\mathrm{Mg}^{2+}$ chelators can be used to induce synchrony of cell division in $S$. pombe in a novel way. This supports the hypothesis that $\mathrm{Mg}^{2+}$ plays an important role in the control of the yeast cell division cycle.

Equipment used in this work was bought with grants from the Science Research Council and G.M.W. was supported by a Science Research Council Studentship.

\section{REFERENCES}

Ahluwalia, B., Duffus, J. H., Paterson, L. J. \& WALKER, G. M. (1978). Synchronization of cell division in the fission yeast Schizosaccharomyces pombe by ethylenediaminetetra-acetic acid. Journal of General Microbiology 106, 261-264.

Albert, A. (1958). Metal-binding agents in chemotherapy: the activation of metals by chelation. Symposia of the Society for General Microbiology 8, 112-138.

Bakke, O. \& Pettersen, E. O. (1976). A fast and accurate method for calculating Engelberg's synchronization index. Cell and Tissue Kinetics 9 , 389-393.

BeLl, C. F. (1977). Metal Chelation: Principles and Applications. Oxford: Clarendon Press.

BERRIDGE, M. J. (1976). Calcium, cyclic nucleotides and cell division. Symposia of the Society for Experimental Biology 30, 219-231.

Brock, T. D. (1967). Novobiocin. In Antibiotics, vol. 1, pp. 651-665. Edited by D. Gottlieb \& P. D. Shaw. Berlin: Springer.

Duffus, J. H. \& Paterson, L. J. (1974a). Control of cell division in yeast using the ionophore A23187 with calcium and magnesium. Nature, London 251, 626-627.

Duffus, J. H. \& Paterson, L. J. (1974b). The cell cycle in the fission yeast Schizosaccharomyces pombe: changes in activity of magnesium dependent ATPase and in total internal magnesium in relation to cell division. Zeitschrift für allgemeine Mikrobiologie 14, 727-729.

ENGELBERG, J. (1961). A method for measuring the degree of synchronization of cell populations. Experimental Cell Research 23, 218-227.

Fraser, R. S. S. \& Creanor, J. (1974). Rapid and selective inhibition of RNA synthesis in yeast by 8-hydroxyquinoline. European Journal of Biochemistry 46, 67-73.

Fraser, R. S. S. \& Creanor, J. (1975). The mechanism of inhibition of ribonucleic acid synthesis by 8 -hydroxyquinoline and the antibiotic lomofungin. Biochemical Journal 147, 401-410.

Harfield, B. \& Tenenhouse, A. (1973). Effect of EGTA on protein release and cyclic AMP accumulation in rat parotid gland. Canadian Journal of Physiology and Pharmacology 51, 997-1001.

Johnson, L. E. \& DieTz, A. (1969). Lomcfungin a new antibiotic produced by Streptomyces lomondensis sp.m. Applied Microbiology 17, 755-759.

Johnston, G. C. \& Singer, R. A. (1978). RNA synthesis and control of cell division in the yeast Saccharomyces cerevisiae. Cell 14, 951-958.

KopeCKÁ, M. (1976). The use of the antibiotic lomofungin for demonstration of nuclei and chromosomes in live yeast cells and protoplasts. Folia microbiologica 21, 406-408.

Mrtchison, J. M. (1970). Physiological and cytological methods for Schizosaccharomyces pombe. Methods in Cell Physiology 4, 131-165.

Mitchison, J. M. \& CreanoR, J. (1971). Induction synchrony in the fission yeast Schizosaccharomyces pombe. Experimental Cell Research 67, 368374.

O'Sullivan, W. J. (1969). Stability constants of metal complexes. In Data for Biochemical Research, pp. 423-439. Edited by R. M. C. Dawson, D. C. Elliot, W. H. Elliot \& K. M. Jones. Oxford: Clarendon Press.

Penman, C. S. \& Duffus, J. H. (1975). 2'-Deoxyadenosine and A23187 as agents for inducing synchrony in the budding yeast, Kluyveromyces fragilis. Journal of General Microbiology 90, 76-80.

RubiN, H. (1975). Central role for magnesium in co-ordinate control of metabolism and growth in animal cells. Proceedings of the National Academy of Sciences of the United States of America 72, 3551-3555. 
Shockman, G. D. \& Lampen, J. O. (1962). Inhibition by antibiotics of the growth of bacterial and yeast protoplasts. Journal of Bacteriology 82, 508-512.

SMITH, D. H. \& Davis, B. D. (1967). Mode of action of novobiocin in Escherichia coli. Journal of Bacteriology 93, 71-79.

Staudenbauer, W. L. (1975). Novobiocin-a specific inhibitor of semiconservative DNA replication in permeabilized Escherichia coli cells. Journal of Molecular Biology 96, 201-205.

TuIo, J. H. \& LEVAN, A. (1950). The use of oxyquinoline in chromosome analysis. Anales de la Estación experimental de Aula Dei 2, 21-63.

WALKER, G. M. (1978). Metal ions and the control of the cell cycle in fission and budding yeast. Ph.D. thesis, Heriot-Watt University, Edinburgh. 